\title{
Para una nueva historia de los hidrocarburos
}

Reseña de Anaya Giorgis, Juan José (2018). Estado y petróleo en Bolivia (siglos XX-XXI). Cochabamba, Agencia Sueca para el Desarrollo Internacional-Universidad Mayor de San Simón, Centro de Estudios de Población, ISBN 97897740229 5; 418 pág

María Cecilia Zuleta

mczuleta@colmex.mx

Centro de Estudios Históricos, El Colegio de México,

México

Cita sugerida: Zuleta, M. C. (2021). Para una nueva historia de los hidrocarburos [Revisión del libro Estado y petróleo en Bolivia (siglos XX-XXI) por J. J. Anaya Giorgis]. Sociohistórica, 48, e153. https://doi.org/10.24215/18521606e153

Estado y petróleo en Bolivia, de Juan José Anaya, expone una notable investigación de ciencias sociales, relevante para los lectores sudamericanos, así como también para interesados en estudios sociales, historia, politología y cuestiones energéticas de Bolivia y Latinoamérica. Se trata de un texto que -resultado de una tesis de doctorado revisada y madurada, presentada en FLACSO Argentina- consigue enriquecer nuestro conocimiento actual sobre la trayectoria política e historia de los hidrocarburos en Latinoamérica.

Anaya Giorgis explica en cinco capítulos y varios anexos la historia de un siglo de políticas para las industrias extractivas hidrocarburíferas en Bolivia. A través de ellos, arroja luz sobre los diversos actores, intereses y prioridades políticas, mecanismos económicos y factores tecnocientíficos que constituyeron 
en cada momento el campo para debates nacionalistas y para la formación de coaliciones favorables a la estatización de estos recursos fósiles. Analiza los dilemas institucionales, políticos, tecno-burocráticos, doctrinarios y geopolíticos alrededor de la extracción y explotación del petróleo y el gas, y explica las raíces y razones del constante movimiento pendular-entre guerras, revoluciones sociales, golpes militares, regímenes dictatoriales y crisis económicas-alrededor de una encrucijada dicotómica: control estatal o apertura a la inversión y explotación extranjera directa.

Anaya demuestra cómo, más allá del cambiante peso económico fiscal de los hidrocarburos en las arcas del estado boliviano (al menos hasta mediados del siglo XX poco significativo frente al estaño) estos combustibles fósiles fueron centrales en la política boliviana, podría decirse, convirtiéndose pues se convirtieron en el combustible, en "el" combustible en la política boliviana, en la política boliviana, aunque los motores fueran otros. Los hidrocarburos no sólo detonaron movilizaciones en las calles, campañas de comunicación y propaganda, negociaciones políticas y pugas tecno burocráticas dentro del aparato gubernamental boliviano y en el sector empresarial público. También, fueron centrales en los proyectos de modernización económica, industrialización y cambio social, y, sobre todo y de forma creciente al avanzar el último tercio del siglo XX, espina dorsal de la geopolítica boliviana.

Bien documentado, este libro se sustenta en una acuciosa recuperación de fuentes recabadas tanto en Bolivia como en la Argentina (incluso en archivos históricos poco consultados y de gran riqueza, como el del Museo de Ciencias Naturales de la Universidad Nacional de La Plata), un denso corpus de bibliografía que rescata textos de difícil acceso publicados en Bolivia, prensa periódica, y un buen número de entrevistas a actores participantes, valiosas, bien seleccionadas y realizadas. Al final, incluye tres anexos, oportunos y con valor para el desarrollo de futuras investigaciones: uno, sobre temas geológicos(un seguimiento de las varias misiones geológicas extranjeras en el país), otro, que reúne y sistematiza información legislativa referente al marco jurídico y regulatorio que rigió la propiedad y explotación de petróleo y gas; y finalmente, un último anexo en el que se sistematiza muy completa información sobre movimientos y organizaciones sociales (campesinas, indígenas, profesionales, gremiales y sindicales, de juventudes, estudiantiles, infancia) cuya agenda de acción colectiva se orientó a impulsar el control estatal de los recursos extractivos.

Estado y petróleo en Bolivia (siglos XX-XXI) desarrolla hipótesis explicativas que polemizan con los estudios e investigaciones disponibles. La reconstrucción de los orígenes de la exploración petrolera en Bolivia es notable y logra aportar información de primera mano y muy original al debate, con fuentes poco conocidas, y una reconstrucción minuciosa de las primeras exploraciones geológicas, las de una etapa preindustrial de la explotación petrolífera. Un aporte adicional del trabajo reside en su contribución a la historia del papel del conocimiento geológico y de la educación tecnológica en el desarrollo de la industria hidrocarburífera previa a la creación de YPFB, y el medio siglo posterior, al iluminar la importancia de los dilemas tecnológico productivos y tecno burocráticos en la gestión de esta empresa estatal, la segunda estatal petrolera más antigua de Latinoamérica, así como su centralidad en las querellas y debates político-doctrinarios en torno al control de los recursos del subsuelo. Esto resulta una contribución valiosa y original en el contexto de las investigaciones disponibles sobre el tema, que proporciona además claves para la comparación del caso boliviano con otras experiencias de explotación e industria de los hidrocarburos en América Latina.

Como contribución adicional, puede decirse que este libro no sólo aporta información y análisis relevante para un mejor conocimiento del siglo XX boliviano, sino que consigue conectar exitosamente las preguntas del presente, de la primera década del siglo XXI y la llamada Guerra del Gas, con el pasado. Es particularmente esclarecedor en tres ámbitos: uno de ellos es la explicación acerca de cómo los recursos naturales son "creados" -no dotados naturalmente-en sincronía con los avances tecnológicos y de la formación y entrenamiento de cuadros técnicos especialmente preparados para detectar, extraer y explotar esos recursos; el otro se refiere a las dinámicas ideológicas y políticas que condujeron a la continua reelaboración de la opinión nacionalista acerca de estos recursos, y que configuraron varios "nacionalismos" que se han ido conformando como diversos estratos de un palimpsesto nacionalista; por último, el impacto de las expectativas de un boom exportador 
gasífero en el diseño de políticas fiscales, estrategias geopolíticas, y demandas sociales, que inciden en la dinámica general energética y política del Cono Sur. La explicación de la lenta transición a la explotación gasífera a partir de innovaciones en el ámbito de la prospección y exploración, y luego, al boom exportador gasífero, que perfila -aunque no se plantea así-unas expectativas y dinámicas de políticas públicas típicas de un Estado rentista, es también una notable aportación del autor.

Por último, aunque se echa en falta el diálogo con los estudios sobre empresas estatales en Latinoamérica -especialmente con la historiografía argentina, mexicana y chilena sobre esta temática, muy rica y pródiga en cuanto a sus horizontes comparativos- algunas secciones son verdaderamente iluminadoras de los momentos de auge y de declive de la compañía estatal YPFB, resaltando la importancia de sus cuadros técnicos y burocráticos en el debate sobre los dilemas de seguridad energética planteados por el boom gasífero, y alrededor de la transnacionalización e integración energética en América del Sur.

El libro, en suma, resulta una contribución en sus hallazgos empíricos y su análisis histórico, así como por los cruces transdisciplinarios que, si no desarrolla, deja abiertos. Visto desde una óptica amplia, ofrece ventanas de diálogo con otros ámbitos de estudio de las ciencias sociales, entre ellos: los estudios energéticos del Cono Sur, los estudios extractivistas, los estudios de movimientos sociales y sobre las izquierdas en Latinoamérica, y también con las investigaciones sobre la génesis e itinerarios de la economía pública en Latinoamérica, y particularmente, del Estado empresario. Este libro, junto a otras recientes investigaciones abre brecha hacia una renovada historia de los hidrocarburos en Bolivia, que deje atrás lugares comunes, aporte nueva información y análisis, y brinde puntos de anclaje para discutir los procesos históricos de integración energética en la América del Sur tema del que la historia como disciplina, junto a las demás ciencias sociales, aún tiene mucho para decir y por debatir.

Útil para la docencia universitaria, y para los investigadores y público en general, Estado y petróleo ha sido recientemente distinguido por la sección Boliviana de Latin American Studies Association (LASA) Premio al mejor libro, con una mención honorífica (Honorable Mention). 